\title{
Resources of hope: Towards a revaluing of education
}

\author{
Paul Stanistreet ${ }^{1}$
}

Published online: 12 February 2020

(c) UNESCO Institute for Lifelong Learning and Springer Nature B.V. 2020

Last year, the adult education movement in Europe marked a number of significant anniversaries associated with the effort to rebuild following the First World War. Among them were 100 years of the Volkshochschulen (adult education centres) in Germany and the centenary of the Final Report of the Adult Education Committee of the Ministry of Reconstruction, better known as the "1919 Report", in the United Kingdom. ${ }^{1}$ Both initiatives stemmed from an appreciation of the costs of failing to foster and sustain democratic citizenship, and expressed a wide vision of the value of education, and of adult education in particular, far removed from the Gradgrindlike $^{2}$ focus on work-related skills and employability that has dominated the education discourse in recent decades.

This year, we mark two other significant anniversaries, associated with the end of the second calamitous world war of the twentieth century: it is 75 years since both the liberation of the Nazi concentration and extermination camp of Auschwitz-Birkenau (International Holocaust Remembrance Day is being marked as I write) and the creation of the United Nations (UN). The UN emerged in part from a determination to ensure that the horrors of the Holocaust, and the oppression and dehumanisation of Jews and other minorities that led to it, did not happen again. This sensibility also shaped the founding values of the United Nations Educational, Scientific and Cultural Organization - UNESCO - which was set up in 1946 with a mandate to construct "the defences of peace" in the minds of women and men.

\footnotetext{
1 Ministry of Reconstruction, Adult Education Committee (1919). Final Report. Parliamentary Papers, House of Commons, Session 1919, vol. 28. Cmd. 321. London: His Majesty's Stationary Office (HMSO).

2 Thomas Gradgrind is a fictional character in Hard Times, a 19th-century novel. He is an educator who insists on teaching children only "hard facts" which they should be able to put to profitable use when they join the workforce. While this reflected the Victorian utilitarian philosophy prevalent at the time this novel was serialised, the author exaggerated Gradgrind's obsession with facts. Dickens, C. (2003 [1854]). Hard times. London: Penguin.
}

Paul Stanistreet

p.stanistreet@unesco.org

1 UNESCO Institute for Lifelong Learning, Hamburg, Germany 
As my colleague Maren Elfert describes in her recent book, ${ }^{3}$ much of UNESCO's early thinking about education was a response to the misuse of education for ideological purposes during the Second World War and the atrocities to which it contributed. A "humanistic and emancipatory approach" emerged, Elfert writes, that "aimed at bringing out the full potential of human beings and enabling them to shape their societies towards greater democratization and social justice" (Elfert 2018, p. 1). Education, UNESCO's founding mothers and fathers recognised, was a human right, with "intrinsic", rather than instrumental, value, and its aim should be to foster a range of social and civic benefits, as well as economic ones, and to produce active, responsible citizens who think critically but not cynically.

This expansive, humanistic vision, developed by UNESCO in its landmark Faure ${ }^{4}$ and Delors ${ }^{5}$ reports, has inspired educators the world over and has occasionally featured in national-level policymaking. However, as the passionate humanism of the immediate post-Second World War years faded, a more instrumentalist philosophy of education took hold, emphasising, to an overwhelming extent, economic outcomes and treating education as means to increased economic productivity and growth. Politicians and policymakers neglected the wider value of education, with some governments more than content to profit from the absence of education for broader human purposes such as active citizenship. This is evident even - or perhaps especially - in the discourse about lifelong learning and adult education, concepts intimately linked to the cultivation of civic and democratic values. Although they often speak the same language, there is a growing divide between the values of groups that advocate lifelong learning and those responsible for planning and implementing education policy.

This should worry us, particularly in light of the broad, holistic intentions of the 17 Sustainable Development Goals and their interconnected nature. It is becoming increasingly evident that this narrow purposing of education is inadequate to the challenges posed by the climate crisis, the technological revolution, gross social and economic inequalities, and demographic change. Most of the articles in this issue reflect, in one way or another, the notion that more of the same will not do, that the certainties of the recent past deserve challenge, and that the way in which we think about and value education requires urgent reappraisal.

The first such challenge comes from authors Kristen H. Perry, Donita M. Shaw and Sara Saberimoghaddam. In their article, "Literacy practices and the Programme for the International Assessment of Adult Competencies (PIAAC): A conceptual critique", they examine the tension between PIAAC's "cognitive orientation" and "its attempt to factor in meaningful literacy practices". Literacy has become an important variable in country comparisons, thanks mainly to large-scale assessments such as PIAAC and the attention they command in the media and among policymakers. However, concerns have grown in the field of adult literacy scholarship that PIAAC, and the International Adult Literacy Survey (IALS) that preceded it, have failed

\footnotetext{
${ }^{3}$ Elfert, M. (2018). UNESCO's utopia of lifelong learning: An intellectual history. New York: Routledge.

${ }^{4}$ Faure, E., Herrera, F., Kaddoura, A.-R., Lopes, H., Petrovsky, A. V., Rahnema, M., \& Champion Ward, F. (1972). Learning to be. The world of education today and tomorrow. Paris: UNESCO/Harrap.

${ }^{5}$ Delors, J., et al. (1996). Learning: The treasure within. Report to UNESCO of the International Commission on Education for the Twenty-first century. Paris: UNESCO.
} 
to do justice to current understandings of literacy practice and have put too much weight on "employment-related aspects of literacy", thus, in the words of Mary Hamilton and David Barton, supporting "the new work-order vision of global capitalism" and encouraging people "to see this as a fixture around which we need to adjust our lives and national policies, rather than something which literacy might help to shape according to a more humanitarian agenda" (Hamilton and Barton 2000, pp. 386, 387). ${ }^{6}$

Perry, Shaw and Saberimoghaddam argue that while PIAAC has made some progress in addressing literacy practices, its conceptualisation does not align well with current theoretical understandings of literacy as social practice. They point, in particular, to its conflation of several key literacy constructs, such as "text", "genre" and "practice", and its neglect of context, purpose, social interaction and power relationships in literary practice. While PIAAC aims to focus on the skills demanded for participation both in " 21 st-century society and the global economy", they write, in reality its focus is on participation in the economy: "To do this issue justice, a broader and deeper exploration of 'everyday life' practices would be needed." The authors conclude by imagining what might happen if literacy practices, rather than individuals" skills, were "foregrounded" and PIAAC interrogated "a broader range of contexts ... probing more deeply into the practices associated with those contexts". This, they suggest, "would provide a broader understanding of how people actually engage with literacy and the ways in which these practices align with other social factors and outcomes".

Also in search of new conceptualisations are Jay Hays and Hayo Reinders in their article "Sustainable learning and education: A curriculum for the future". The authors introduce sustainable learning and education (SLE), which they describe as "an emerging philosophy of learning and teaching founded on principles of sustainability". SLE, they write, is "not education for or about sustainability" but, rather, it is "sustainable learning, a new and different concept ... understood as learning that is retained (and may be transferable) after initial exposure to it and may involve a process of "learning to learn"'. More particularly, it involves "ongoing, purposeful, responsive and proactive learning; the learner effectively builds and rebuilds her or his knowledge and skills base as circumstances change". This is a very interesting notion, which resonates strongly with the concept of lifelong learning, particularly in its intention "to instil in people the skills and dispositions to thrive in complicated, challenging and ever-changing circumstances, and contribute to making the world a better place". Hays and Reinders explain the concept and enumerate the principles of sustainability that might guide the design, delivery and evaluation of courses, before proposing a curriculum for SLE framed as a university course or professional development programme.

As the authors note, few courses of the kind proposed have been developed, and learning and education remain "relatively unexplored as expressions of sustainability". Nevertheless, they argue, there is a strong need for them, emerging from the increasing demand for education to not only foster a love of learning, but also equip

\footnotetext{
${ }^{6}$ Hamilton, M., \& Barton, D. (2000). The International Adult Literacy Survey: What does it really measure? International Review of Education, 46(5), 377-389.
} 
learners with "the skills, dispositions and discipline to continually learn and to apply that learning towards ends - innovations - that contribute to long-term global flourishing". Hays and Reinders conclude by arguing that sustainability is "essentially a matter of community", whether community is understood as referring to "our workplace, neighbourhood, nation or planet": "Ultimately, what we do as individuals and collectives impacts others at some level of community. If we cared more about those communities we do not see and experience every day, including future generations, we might also think more deeply about our actions and their consequences ... We must learn (and change) now and into the future".

"Literacy for self-reliance: A critical exploration of Nyerere's legacy in Tanzanian education policies", by Kapil Dev Regmi, Samuel Andema and Marlene Asselin, is also rooted in the challenges of sustainability. The authors contrast the need for stronger international connections and cooperation to deliver the 17 Sustainable Development Goals (SDGs) of the United Nations' 2030 Agenda with the troubling rise in nationalism and protectionism in countries such as the United States and the United Kingdom. In this context, the authors write, "Julius Nyerere's $e d u$ cation for self-reliance (ESR) philosophy, which aimed at achieving sustainable development using Tanzania's own resources (rather than through development aid from foreign donors), has again gained traction among scholars and policymakers". Nyerere believed that Tanzania could achieve self-reliance "through state investment in socio-economic production and education". Unhappily, while his presidency was marked by some significant developments in education, notably in adult education and literacy, economic and political shocks meant that Tanzania "was obliged to create an investment-friendly climate for foreign donors in several sectors, including education".

Regmi, Andema and Asselin critically analyse key education policy documents produced by Tanzania and its development partners from independence to the present day, with a particular focus on literacy, with a view to evaluating the extent to which "literacy for self-reliance" has been included in national education policies and the extent to which it remains relevant to literacy education. Nyerere believed that literacy should help people "think clearly" and enable them "to examine the possible alternative course of action" and "translate their decisions into reality" (Lema et al. 2004, p. 134). ${ }^{7}$ The authors' analysis shows that, even though ESR is mentioned in literacy policies, the term "self-reliance" has acquired new connotations: literacy is understood as comprising students' abilities in basic reading, writing and arithmetic; and current literacy initiatives are designed to prepare Tanzanians for work rather than empowering rural communities for sustainable development. This attenuated vision of literacy education reflects, of course, the wider drift away from broader, humanistic appreciations of education towards more economic, instrumental interpretations. However, as the authors argue in concluding, the obvious challenges in achieving the SDGs through donor aid, notably the retreat of some donor countries into political isolationism, mean that now is perhaps a good time to revisit Nyerere's ideas and re-evaluate his legacy in Tanzania.

\footnotetext{
${ }^{7}$ Lema, E., Mbilinyi, M.J., \& Rajani, R. (Eds) (2004). Nyerere on education: Selected essays and speeches. Dar es Salaam: The Mwalimu Nyerere Foundation.
} 
Self-reliance and autonomy are important concepts also in the development of open and distance learning. The advent of massive open online courses (MOOCs) carried for many commentators the promise of a form of learning that was free, flexible, open and democratic, and that had the potential to widen access to higher education in significant ways. However, as István Danka points out in his article entitled "Motivation by gamification: Adapting motivational tools of massively multiplayer online role-playing games (MMORPGs) for peer-to-peer assessment in connectivist massive open online courses (cMOOCs)", while enrolment in "connectivist" MOOCs (MOOCs that emphasise a collaborative approach to learning) is high, completion rates are extremely low, and courses often "lack an appropriate method of evaluating learning progress and motivational resources". The fact that a large proportion of MOOC learners do not finish their courses points to motivation being a central problem for MOOCs in their current design and conceptualisation. In his thoughtful account, Danka suggests that one way of addressing the problem is through adapting motivational formative assessment tools used in massively multiplayer online role-playing games - or MMORPGs. He notes in particular three motivational characteristics of online role-playing games: character generation and the process of identity construction; constant progress monitoring and instant feedback through "experience points" and the "levelling up"; and interactive progress via user-defined goals, characterised by a high degree of collaboration.

Danka supports the principles of connectivism, which characterise most MOOCs, and particularly the democratic principles of autonomy, diversity, openness and interactivity, which, he argues, represent the "best scenario for fruitful peer-to-peer connections". And although these principles may be considered problematic in that learners participating on this basis do not always seem motivated to stay (on) the course, he contends that some motivational characteristics of MMORPGs can be effectively incorporated into cMOOCs without compromising connectivist principles. In particular, the article points to the potential of MMORPGs' formative, peerto-peer assessment as a solution to the problem of motivation, arguing that while assessment may, on the face of it, seem incompatible with connectivism, the incompatibility can be dissolved if assessment is "understood in a connectivist spirit". Danka does not suggest that gamification is the only or best way to address the motivational problem with MOOCs, but he does demonstrate that there is a great deal of scope here for further research and reflection. While some of the early enthusiasm about MOOCs has been replaced with scepticism, or at least a more modest sense of ambition, this article indicates that there is still rich potential to be tapped, if we are prepared to think a little differently.

"The potential of Accelerated Learning Programmes (ALPs) for conflict-ridden countries and regions: Lessons learned from an experience in Iraq", by Moritz Bilagher and Amit Kaushik, also considers student engagement in learning, but from a quite different perspective. The article examines the Iraq Accelerated Learning Programme (ALP), set up in 2005 by the Government of Iraq, in partnership with the United Nations Children's Fund (UNICEF), to provide a "fast-track secondchance opportunity to complete formal education" to excluded children and young people. The programme aimed to give 50,000 "out-of-school, often traumatised and disenfranchised" children aged between 12 and 18 years, whose education had been 
disrupted by conflict, an opportunity to complete the six-year primary education cycle in three years and move on to further general education, vocational training or work. Bilagher and Kaushik discuss the findings of an evaluation of the programme conducted in 2008, drawing out lessons that could apply to other conflict-ridden countries and regions.

The evaluation data imply that the programme addressed a significant need and that it was appreciated by the target group, with 75 per cent of learners stating that they "liked it very much" and a further 18 per cent saying they "liked it". Around 90 per cent of ALP graduates either continued in secondary education, or were otherwise studying in other programmes, engaged in an apprenticeship scheme or in employment. Interestingly, both survey and interview data suggest that the Iraq ALP did more than create educational opportunities for young people, important though this is. It also enabled them to obtain a "confident perspective for their own future in their own country". As most educators will recognise, a sense of hope for the future can be critical in engaging learners, particularly those who are most vulnerable and disadvantaged. The job of education is to offer such learners "resources of hope", in Raymond Williams' glorious phrase. ${ }^{8}$ As the authors note, it can also be key in making young people less vulnerable to participation in extreme or "subversive" activities, such as joining militias. This finding and the other data on the Iraq programme suggest that interventions such as this one have the potential to impact very positively on the lives of young people in conflict-affected countries.

As this article indicates, the moment in which we live is one of acute challenge and, for very many people, hopelessness. Migration and the forced displacement of large numbers of people are putting unprecedented strain on public services, including education, while creating populations that are more diverse. The technological revolution, including the development of artificial intelligence, increased automation and the wide use of information and communications technology (ICTs), is changing the world of work and redrawing social boundaries, while posing new ethical questions concerning access, scrutiny and control. And the climate crisis is forcing us to reconsider the way in which we live, and question the principle of endless economic growth and our tolerance of appalling levels of injustice and inequality. We need to create a "new normal", both in education and in wider society; something more than a sophisticated way of maintaining our change-resistant status quo.

This is why the work of UNESCO's Futures of Education commission ${ }^{9}$ is so critical and why so much is expected of it. It coincides with and should inform the increased policy attention that has been given to lifelong learning since it emerged as a crucial dimension of the fourth Sustainable Development Goal (SDG 4), which concerns education. Critically, the commission needs to create a space in which people feel empowered and inspired to disrupt and resist, to be imaginative and open, and to create something new and different. It is to be hoped that that the commission's ambitions prove equal to the challenge, and that the outcomes command greater and more sustained interest than did those of its predecessors,

\footnotetext{
8 Williams, R. (1989). Resources of hope. London: Verso.

${ }^{9}$ For more information, visit https://en.unesco.org/futuresofeducation/ [accessed 4 February 2020].
} 
the commissions headed by Edgar Faure and Jacques Delors. As the founders of UNESCO, and the progenitors of the adult education movement in Germany and the United Kingdom understood, the purpose of education cannot be reduced to the creation of productive economic units. Its purpose is, rather, to foster the development of a better society - a learning society in which people are empowered to change the future instead of being prepared for a future they did not choose and cannot control.

Acknowledgements As this is the first issue of 2020, I would like to conclude by acknowledging the support provided by our peer reviewers during 2019. Without them, this journal could not exist. I therefore extend my deepest gratitude and appreciation to the following individuals (listed in alphabetical order) who reviewed articles for IRE last year: Helen Abadzi, University of Texas at Arlington, United States of America; Christel Adick, Ruhr University Bochum, Germany; Hassana Alidou, University of Cincinnati, USA; Harald Ansen, Hamburg University of Applied Sciences, Germany; Margot Barry, HAN University of Applied Sciences, The Netherlands; Stephanie Bengtsson, UNESCO International Institute for Educational Planning, France; Moritz Bilagher, UNESCO Internal Oversight Service (IOS) Evaluation Office, France; Mark Bray, University of Hong Kong, Hong Kong SAR, China; Mie Buhl, Aalborg University, Denmark; JD Carpentieri, University College London Institute of Education, United Kingdom; Andreas Fejes, Linköping University, Sweden; Joseph Giordmaina, University of Malta, Malta; Daphne Greenberg, Georgia State University, United States of America; Anke Grotlüschen, University of Hamburg, Germany; Heribert Hinzen, DVV International, Germany; John D. Holst, Pennsylvania State University; United States of America; Maysa Jalbout, The Brookings Institution, United States of America; Zellynne Jennings, The University of the West Indies, Jamaica; Anna Kaiper, Pennsylvania State University, United States of America; Michael McVey, Eastern Michigan University, United States of America; Maria Paula Meneses, University of Coimbra, Portugal; Silvia Elisabeth Moraes, University of Ceará, Brazil; Stanley Mpofu, National University of Science \& Technology, Zimbabwe; Norbert Nikièma, University of Ouagadougou, Burkina Faso; Dietmar Klaus Pfeiffer, Westphalian Wilhelms-University Münster, Germany; Steffi Robak, University of Hannover, Germany; Alan Rogers, University of East Anglia, United Kingdom; Cristine Smith, University of Massachusetts, United States of America; Suzanne Smythe, Simon Fraser University, Canada; Touorizou Hervé Somé, Ripon College, United States of America; Crain Soudien, University of Cape Town, South Africa; Darko Štrajn, Educational Research Institute, Slovenia; Alan Tuckett, University of Wolverhampton, United Kingdom; Yuka Uzuki, National Institute for Educational Policy Research, Japan; Alexander W. Wiseman, Texas Tech University, United States of America; and Joseph Zajda, Australian Catholic University, Australia.

Publisher's Note Springer Nature remains neutral with regard to jurisdictional claims in published maps and institutional affiliations. 